\title{
2-2 関西マルチメディアサービス研究会の活動
}

土 森 紀 之 $之^{\dagger}$ 津 野 勝 信 $^{+\dagger}$

\section{1. まえがき}

関西マルチメディアサービス研究会 (以下, 研究会 という) は, 関西電力(株) と住友商事(株)を代表幹事 会社として, 電気通信事業者, ケーブルテレビ会社, メーカその他, マルチメディア関連企業など約 60 社 から構成されている団体である。

ケーブルテレビのネットワークは, 双方向に高速で かつ大容量の情報伝送を低コストで実現できる可能性 を有しており，また，すでに利用者への充実したアク セス回線を形成していることから，このケーブルテレ ビのネットワークを地域系 NCC (New Common Corrier)の大阪メディアポート(株) (OMP)の光ファイバ で広域的に連携し，設備の共有化を図ることにより効 率的なネットワークを形成し，マルチメディアサービ スにかかわる技術検証, 市場性検証等を行うことを目 的としている.

実験期間は平成 8 年 10 月から 1 年間で, 現在, ケ ーブルテレビ 7 社がこの実験に参画している. 実験内 容は, 高速インターネット接続を主題としたCATV$\mathrm{LAN}$ (以下, LAN/Cという)と, 電話, パソコン通 信やダイヤルアップインターネット接続を主題とした CATV 電話(以下, TEL/C という)の 2 つを柱として いる.

\section{2. ケーブルテレビ局の実験参画}

現在, 大阪ケーブルテレビ(株) (OCT), 大阪セン トラルケーブルネットワーク ( $\mathrm{OCCN})$, (株)シティウ エーブ大阪 $(\mathrm{CWO}),($ 株) 京阪ケーブルテレビジョン (K-CAT)，近鉄ケーブルネットワーク(株) $(\mathrm{KCN})$, (株)チャンネルウェーブあまがさき (CWA)，（株)京 都ケーブルコミュニケーションズ $(\mathrm{KKCC})$ の 7 局で 運用・実験を行っている。

$\dagger$ 関西電力株式会社

†大阪メディアポート株式会社

"An Overview of CATV Multimedia Services Trial" by Noriyuki Tsutimori (Kansai Electric Power Co. Ltd., Osaka) and Masanobu Tsuno (Osaka Media Port Corporation, Osaka)
上記のうち, LAN/C 実験は全局にて実施している が, TEL/C 実験は 3 局 (OCT, OCCN, K-CAT) の実験である。

なお，本年 8 月より，(株)ケーブルビジョンアイ (CVi) が $\mathrm{LAN} / \mathrm{C}$ 実験に参画した.

各ケーブルテレビ局の実験条件は様々であるが, 実 験に使用している周波数带域と実験設備およびモニ夕 数は表 1 のと抢りである.

\section{3. コアセンタについて}

これら 7 つケーブルテレビ局を結合するために， OMP のネットワークセンタ内にコアセンタを設置 し, 専用線や ISDN 網を活用して有機的に接続して いる.

そして，インターネットKDDによるインターネッ 卜接続, パソコン通信事業者との接続, FAX 情報提 供者との接続, 新世代通信網実験協議会 $(\mathrm{BBCC})$, 加 えてコンテンツ提供者等との接続を行っている.

全体の構成概要は図1のとおりである.

\section{$3.1 \mathrm{LAN} / \mathrm{C}$ の構成について}

バリアセグメントの境界に FIREWALLを設けた， イントラネット構成になっている.内部 LAN は, WWW サーバ, メールサーバ, カラオケサーバ等に より構成され，マルチメディア度を重視したサービ ス, すなわち静止画, 文字に加え映像, 音楽を含めた サービス提供を行っている.さらにCU-SeeMeリフ レクタを具備し，モニタ相互間のインタラクティブな サービス提供も行っている.

OMP〜ケーブルテレビ局の専用線は, $192 \mathrm{~kb} / \mathrm{s}$ か ら開始し, $384 \mathrm{~kb} / \mathrm{s}$ を経て, 現在は $768 \mathrm{~kb} / \mathrm{s}$ での速 度であり, 近日中に $1.5 \mathrm{Mb} / \mathrm{s}$ に増速する予定であ る。(ただし，KCATのみは $6 \mathrm{M}$ 利用固定としてい る)

インターネットKDD 接続は, $512 \mathrm{~kb} / \mathrm{s}$ から開始 し, 現在は $1 \mathrm{Mb} / \mathrm{s}$ の速度である. 研究会は, モニタ 数や利用状況 (トラフィック・アクセス数), あるいは サービス内容の拡充に伴って, それらをパラメータと して実験条件を改善しながら実験を行っている。 
表 1 ケーブルテレビ局の実験参画状況

(a) $\mathrm{TEL} / \mathrm{C}$

\begin{tabular}{|c|c|c|c|c|}
\hline & \multicolumn{2}{|c|}{ 実験使用周波数 (MHz) } & \multirow{2}{*}{ 実験設備 (交換機) } & \multirow{2}{*}{$\begin{array}{l}\text { モ二夕数 } \\
\text { (7 月現在) }\end{array}$} \\
\hline & 上り & 下り & & \\
\hline OCT & $32 \sim 36$ & $692 \sim 698$ (U 50) & NEC 製 NEAX $61 \mathrm{~J}$ & $51(29)$ \\
\hline $\mathrm{OCCN}$ & $36 \sim 42$ & $230 \sim 236(\mathrm{C} 24)$ & 松下製 PBX & $45(10)$ \\
\hline $\mathrm{K}-\mathrm{CAT}$ & $30 \sim 36$ & $248 \sim 254($ C 27$)$ & NEC 製 PBX & $55(38)$ \\
\hline
\end{tabular}

（注）モニ夕数の（）内数字は, そのうちのダイヤルアップインターネット利用者数

$\mathrm{U}: \mathrm{UHF}$ の channel, 周波数帯 $(6 \mathrm{MHz}) \quad \mathrm{C}:$ Channel

(b) $\mathrm{LAN} / \mathrm{C}$

\begin{tabular}{|c|c|c|c|c|}
\hline \multirow{3}{*}{ OCT } & \multicolumn{2}{|c|}{ 実験使用周波数 $(\mathrm{MHz})$} & \multirow{2}{*}{ 実験設備 (ケーブルモデム) } & \multirow{2}{*}{$\begin{array}{l}\text { モニ夕数 } \\
\text { (7 月現在) }\end{array}$} \\
\hline & 上り & 下り & & \\
\hline & $28 \sim 32$ & $252 \sim 258$ (C 28) & シャープ製 非対称型 $40 \mathrm{M} / 2 \mathrm{M}$ & 3 \\
\hline $\mathrm{OCCN}$ & $18 \sim 24$ & $384 \sim 390$ (C 50) & LANCity 製 対称型 $10 \mathrm{M} / 10 \mathrm{M}$ & 59 \\
\hline $\mathrm{CWO}$ & $42 \sim 48$ & $236 \sim 242(\mathrm{C} 25)$ & Zenith 製 刘称型 $4 \mathrm{M} / 4 \mathrm{M}$ & 43 \\
\hline $\mathrm{K}-\mathrm{CAT}$ & $24 \sim 30$ & $242 \sim 248$ (C 26) & NEC 製 非対称型 $30 \mathrm{M} / 2 \mathrm{M}$ & 21 \\
\hline $\mathrm{KCN}$ & $36 \sim 42$ & $432 \sim 438(\mathrm{C} 58)$ & LANCity 製 対称型 $10 \mathrm{M} / 10 \mathrm{M}$ & 28 \\
\hline CWA & $42 \sim 48$ & $236 \sim 242$ (C 25) & NEC 製 非対称型 $30 \mathrm{M} / 2 \mathrm{M}$ & 48 \\
\hline $\mathrm{KKCC}$ & $30 \sim 36$ & $548 \sim 548(\mathrm{U} 25)$ & 富士通製 非対称型 $8 \mathrm{M} / 2 \mathrm{M}$ & 25 \\
\hline
\end{tabular}

（注）ケーブルモデムの数字は DOWN/UPの転送速度を示す．

一方，ケーブルテレビ局の LAN には，キャッシン グ(http 等)を行う cache ${ }^{* 1}$ サーバを設置し，人気の 高いコンテンツに短時間でアクセスしうるよう工夫を している.

前述のと扔り，ケーブルテレビ局〜モ二夕間の通信 を行うケーブルモデムの仕様は様々で, 変復調方式, 伝送速度，アドレス管理方式，セキュリティ機能，品 質制御 $(\mathrm{QOS})$ 等仕様は異なっているが，ここでは割愛 する.

次に，コアセンタのネットワーク管理の概要につき 説明する。

ルータからの $\mathrm{MIB}^{* 2}$ 情報や, 各種機器からの $\mathrm{SNMP}^{* 3}$ 情報は監視サーバに転送され，そこで統計 処理を行っている. cacheサーバ等に蓄積された LOG 情報は，管理サーバに転送され，そこでアクセ ス数の統計処理を行っている。また，クライアント情 報は， $\mathrm{DNS}^{* 4}$ サーバにて一元管理されている。

ルーチング制御は，各ルータからの RIP 情報を受 信するダイナミックルーチングを採用している．

FIREWALL は，アドレス変換(NAT) とコンテン ツ保護の目的のため設置している。外部 LAN には, 公開 WWW サーバを設け，重量級のコンテンツを割 愛した情報にいつでも誰でもアクセスできるようにし ている。

\section{$3.2 \mathrm{TEL} / \mathrm{C}$ の構成について}

TEL/C 実験は，モニ夕が域内電話，NTT 網接続， OMP 接続（ダイヤルインターネット接続，ニフティ サーブ接続， PC-VAN 接続，FAX 情報提供）のい ずれも利用できる，多目的なサービスを提供してい る。

ケーブルテレビ局に設置した交換機（OCT は局用 変換機で他はPBXを使用) は, OMP 接続番号と NTT 接続番号を識別し，かつダイヤルイン接続とそ れらの課金ができる仕様になっている。

したがって，モニ夕には OMP 接続番号と NTT 接 続番号両方が付与され，しかも両接続番号の加入者番 号は同じ番号で付与されている.

${ }^{* 1}$ Cache：情報（コンテンツ）の貯蔵庫。いったんアクセス した情報をキャッシュに貯蔵し，クライアント端末から同 じ要求があるとキャッシュ内の情報を渡す。

*2 MIB : Management Information Base,ネットワーク管 理情報の構成抢よびデータベースの総称を指す. SNMP も MIB データのうちのひとつである.

*3 SNMP : Single Network Management Protocol, TCP/ IP を使用するホストコンピュータおよびネットワーク構 成機器を管理するためのプロトコルである. システムとし て,マネージャ機能により装置の監視や制御を行う.

${ }^{* 4}$ DNS : Domain Namc System, ホストおよびネットワー ク機器の名前やIPアドレスを管理するシステムであり、 名前に関する管理をTree 構造の階層管理により実現して いる。 


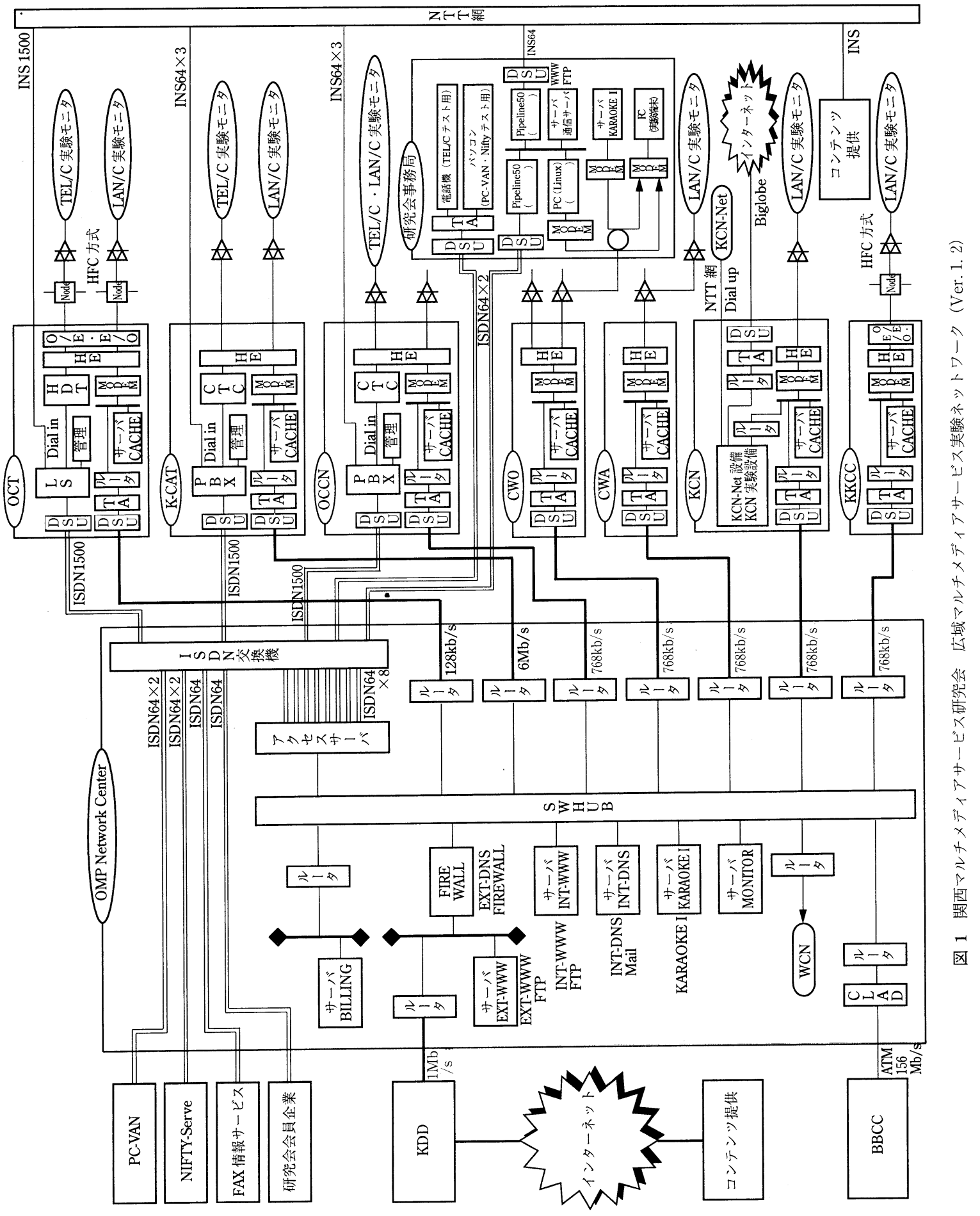


なお, OMP は, 数年前から ISDN 交換サービスを 商用化しており，本実験はそのインフラを活用してい る. OMP〜ケーブルテレビ局間の接続は, ISDN $1500(23 \mathrm{~B}+\mathrm{D})$ を利用している.

次にダイヤルアップインターネット接続の概要につ き述べる。

ダイヤルアップインターネット接続のため, アクセ スサーバが ISDN 変換機と内部 LAN との間に設けら れている。なお, 認証サーバ $\left(\right.$ RADIUS $\left.^{* 5}\right)$ を設け, 確 認プロトロルは $\mathrm{CHAP}^{* 6}$ を用いている.

本実験のダイヤルアップインターネットには接続形 態が 2 つる。すなわち, 会員企業を対象とした ISDN 接続型とモニ夕を対象とした音声接続型であ る.

\section{4. 相互運用について}

研究会は, OMP ならびにケーブルテレビ局と, 実

*5 RADIUS : Remote Authentication Dial-In User Service，米国リビングストン・エンタープライゼスが開発し たユーザ認証技術．研究会は，ダイヤルアップ認証システ ムをクライアント端末, アクセスサーバ, 認証サーバで構 成し，認証サーバとしてRADIUS を使用した。

${ }^{* 6}$ CHAP : Challenge Handshake Authentication Proto col, ダイヤルアップ認証システムのプロトコルを指す． 一般に, クライアント端末とアクセスサーバの認証方法 は, CHAPの他には, PAP (Password Authentication Protocol）が広く用いられている.
表 2 実験提供サービスとそのモ二夕参加内容条件

\begin{tabular}{l|l|l}
\hline \hline \multicolumn{2}{c|}{ 実験提供サービス } & \multicolumn{1}{c}{ モニタ参加内容条件 } \\
\hline LAN/C & インターネッ KDD利用 & モニタ負担は月額 1,000 円 \\
\cline { 2 - 3 } サービス & 機器貸与 & $\begin{array}{l}\text { ケーブルモデムならびにイーサ } \\
\text { ネットボードを無償貸与 }\end{array}$ \\
\hline \multirow{3}{*}{$\begin{array}{l}\text { TEL/C } \\
\text { サービス }\end{array}$} & NTT 利用 & $80 \%$ \%゙モニ負担 (差額は研究会負担) \\
\cline { 2 - 3 } & OMP 利用 & 回線料は無料 \\
\cline { 2 - 3 } & 機器貸与 & モニタに電話機を無償貸与 \\
\hline
\end{tabular}

験が円滑に運用されることを目的として，相互運用に かかる仕様・条件を定め, 各々の役割を明確にした上 でサービス提供を行っている。

\section{5. 実験提供サービスと料金}

研究会はサービス市場性を検証するため，モ二夕を 募集し，そのサービスと参加内容につき条件を定め た。な押，モニ夕選定はケーブルテレビ局にて行っ た。

実験提供サービスとそのモニ夕参加内容条件は, 表 2 のとおり

\section{6. 情報提供サービス}

\section{1「サクサク KANSAI」}

研究会は, ケーブルテレビの持つ高速, 大容量伝送

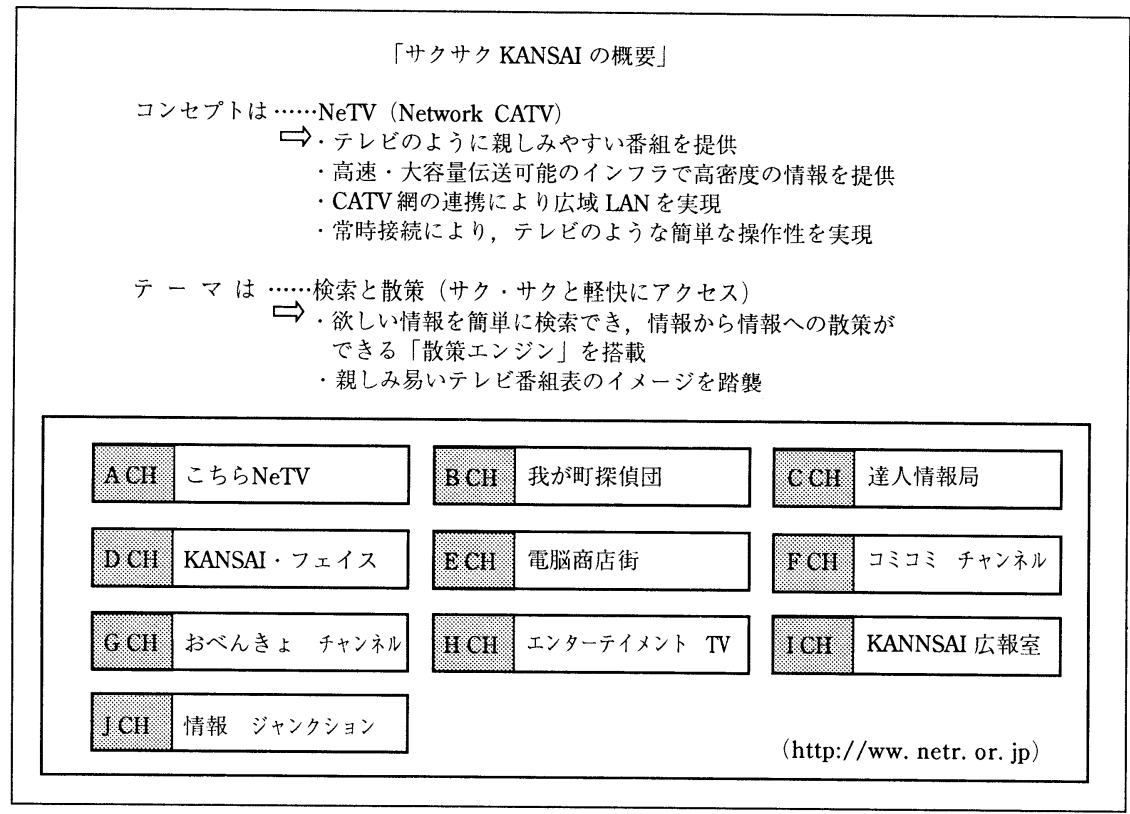

図 2 サクサク KANSAI の概要 
が可能, 地域密着型という特長をフルに活用するた め, 単なる接続サービスだけではなく, アプリケーシ ヨンやコンテンツの分野に大きな力を注いでいる.

研究会のホームページ「サクサク KANSAI」の概 要は図 2 のとおりである.

散策エンジンには，コンテンツ提供者がWebから ダイレクトにページ書込みができる「登録機能」, 登 録内容を管理者が簡単に検閲・審査できる「認証機 能」,および登録情報を自動的にブラウザ上に番組一 覽表として表示する「ページ生成機能」を具備してい る。いわば，単なる閲覧ではなく，インタラクティブ なオンラインマガジンを指向している.

以下に番組内容の一部とその特徵を紹介する。

Aチャンネル：これら NeTV……研究会のすべて を紹介します。

〈研究会からのお知らせ, HOW TO FAQ Archive, モニターズサロン， イベント等〉

Bチャンネル：我が町探偵団……地域密着情報を提 供するテストチャンネル

〈おもろいでっせ大阪, おこしやす京 都, 元気です兵庫, ウェルカム奈良 等〉

Cチャンネル：達人情報局……関西の達人を紹介す るテストチャンネル

〈青春ちんちんどんどん, アマから横 町, ホテルの達人, 未来予測の達人 等〉

Dチャンネル：KANSAI フェース……般市民の 作品を紹介するテストチャンネル

〈ショートストーリー, 写真館, 絵画 展，個人 HP>

$\mathrm{E}$ チャンネル：電脳商店街……イバーモールビジ ネスのテストチャンネル

駒川商店街, O-KiNiCity, Curiocity, ファンタージェン, OBP 紹 介等〉

Fチャンネル：コミコミチャンネル……タウン誌, 回覽版等のテストチャンネル くぱど, 読売新聞, 伝言版, イベント カレンダー〉

Gチャンネル：おべんきょチャンネル……ードー エジュテイメントのテストチャンネ ル

くクイズ, もの知りエース, レシピ, おべんきょう部屋「理科」等〉
Hチャンネル：エンターテイメント TV ……辂楽情 報のテストチャンネル

〈カラオケ,ゲーム, ライブカメラ 「金魚めいわく」，映画予告等〉

I チャンネル：KANSAI 広報室……公共情報のテ ストチャンネル

〈公共情報, ターミナル終電情報, ボ ランティア情報, 電気・ガス情報 等〉

Jチャンネル : 情報ジャンクション……ネットサー フィン用

〈日本の検索エンジン, 研究会会員企 業のページにリンク〉

\section{2 カラオケ・オンデマンド}

研究会では, カラオケ・オンデマンド(古河電気工 業(株)開発)の実証実験を行っている. 本システムは, 一般に普及している MIDI 方式と異なり, 曲目毎に生 の楽器演奏の音やコーラスなどの生の音声を含む表現 豊かな音楽情報を含み, かつ曲にマッチした画像を曲 目毎に提供し, 音楽情報や画像情報をディジタル圧縮 (準 MPEG-1 を採用)して配信する.

配信方式は, CWO モニタの場合は局内配信, 他ケ ーブルテレビモニタの場合は OMP 内のコアセンタに 設置したカラオケサーバからの中央配信 (FTP) とし ている。

また, 本システムはカラオケ利用の他に, 歌手の肉 声を再生したジュークボックスとしての利用ができ る.

なお,いつたんパソコンのキャッシュに蓄積される と 5 回まで再生が可能で, 5 回の再生が終了すると揮 発する仕組みになっている，加えて，本サービスはモ ニタ限定サービスである.

実験は, 平成 9 年 3 月より開始し, 当初 100 曲であ ったが, その後の増曲により 7 月末では 180 曲であ る。

なお，実験を通じて，コンテンツの圧縮率の向上， ストリーム機能の対応，および認証・課金システムの 検証を行う予定である.

\section{3 その他のサービス}

研究会では, 内部 WWWサーバに CU-SeeMe リフレクタを搭載し，モニタ相互間で CU-SeeMeに よるインタラクティブな電子会議の場を提供してい る. 近い将来, 公開リフレクタとして一般の人が利用

\footnotetext{
${ }^{* 7} \mathrm{Cu}$-SeeMe: 米 WhifePineSoftware. inc が 開発した, $\mathrm{UDP} / \mathrm{IP}$ を用いた, インターネットでの電子会議シスう 厶.
} 


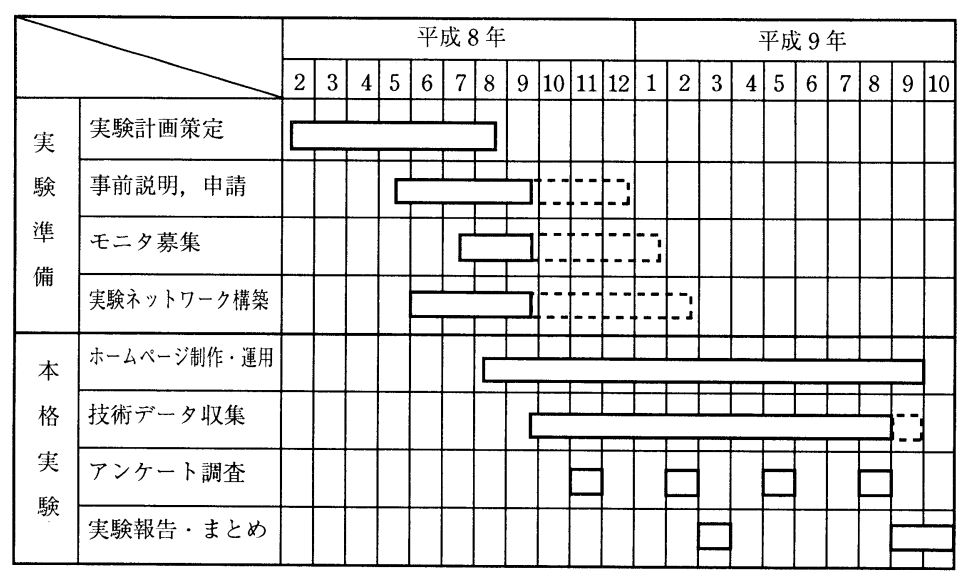

図 3 マルチメディアサービス実験スケジュール

できるようにしたいと考えている。

なお, 近日中に VODLive サービスやピクチャメー ルサービスの提供を行う予定である.

\section{7. 研究会のスケジュール}

研究会は, 図 3 の活動スケジュールに従ってその活 動を行っている.

\section{8. む す び}

通信・放送・コンピュータの融合の時代を迎えてい る. 研究会は, ドメイン名「NeTV」の通り, CATV を有機的に結合してインターネットに代表されるマル チメディアサービスを, テレビのように親しみ易いサ ービスとして広く生活に浸透させていきたいと考えて いる。そして，ケーブルテレビは今最も現実的で有効
な手段と考えている.

研究会は, 本サービス実験を通じて, ケーブルテレ ビ事業の振興と地域の高度情報化の促進に寄与してい きたいと考えている.

(1997 年 7 月 31 日受付)

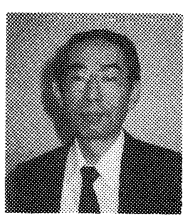

土森 紀之 1968 年, 大阪大学工学部電 気工学科修士課程修了. 同年, 関西電力 (株) に入社. 以来, 制御・通信業務に従事. 現 在, 関西電力 (株) 情報通信室通信システム部 長兼関西マルチメディアサービス研究会事務 局長。専門は制御・通信.

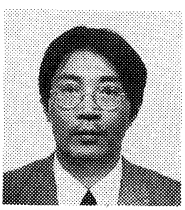

津野勝信 1977 年, 神戸大学工学部電 気工学科卒業。現在, 大阪メディアポート (株) 施設部に勤務し, 通信設備の構築に従事 (課長代理)。関西マルチメディアサービス研 究会事務局技術チームリーダー。專門は通 信. 